Journal

of Geography,

Politics and Society

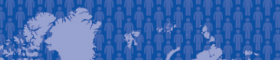

and

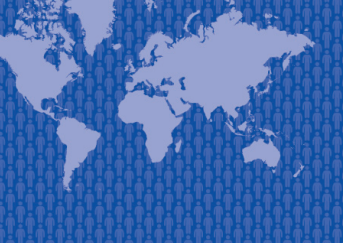

$7(4) / 2017$

\section{Journal of Geography, Politics and Society}

$2017,7(4), 14-24$

DOI 10.4467/24512249JG.17.033.7633

\title{
CENTER-PERIPHERY PROCESSES AND URBANIZATION STADIALITY IN BELARUS
}

\author{
Henadzi Rydzeuski \\ Mogilev Regional Center of Social and Economic Researches, Economy Research Institute, Ministry of Economy of the Republic of Belarus, Boldina 4, \\ 212030 Mogilev, Belarus, \\ e-mail: ridgeo@yandex.ru
}

\section{Citation}

Rydzeuski H., 2017, Center-periphery processes and urbanization stadiality in Belarus, Journal of Geography, Politics and Society, 7(4), 14-24.

\begin{abstract}
Basing on active and hierarchically organized center-periphery processes, functional typology of urban settlements of Belarus is presented and stages of the country's urbanization development are revealed. This functional typology of urban settlements reflects their role in settlement systems and urbanization stages are marked out in view of growth or decline of population in urban settlements of any functional type. Such a concept which reflects urbanization stages of urban settlements performing different functions in hierarchically organized settlement systems can be called the functional urbanization concept. Revealed urbanization stages indicate competition of polycentric and monocentric models of the territorial structure of Belarus during the second half of the 20th century and the beginning of the 21st century. As monocentric development generates overconcentration of the population, economy and environmental management processes and intensifies social, economic and environmental problems, the country's optimum development strategy should be the polycentric one, which can be achieved through active regional policy aimed at sustainable and inclusive development.
\end{abstract}

\section{Key words}

center-periphery processes, social, ecological and economic regions, functional types of urban settlements, urbanization stages, regional policy, Republic of Belarus.

Received: 05 May 2017 Accepted: 23 August 2017 Published: 29 December 2017

\section{Introduction}

Stadiality of development of urban settlements is one of popular subjects of scientific researches and classical researches of J. Gibbs (1963) are particularly famous in this field. He marked out five consecutive stages of urbanization (fig. 1), namely: pre-urbanization (villages grow faster than towns); initial urbanization (towns grow faster than villages); classical urbanization (villages depopulate due to urban drift); late urbanization (it is an apogee of growth of large cities but villages and small towns lose their population); and equalization of growth rates of different size settlements as a result of population deconcentration (this stage later became known as counterurbanization). 


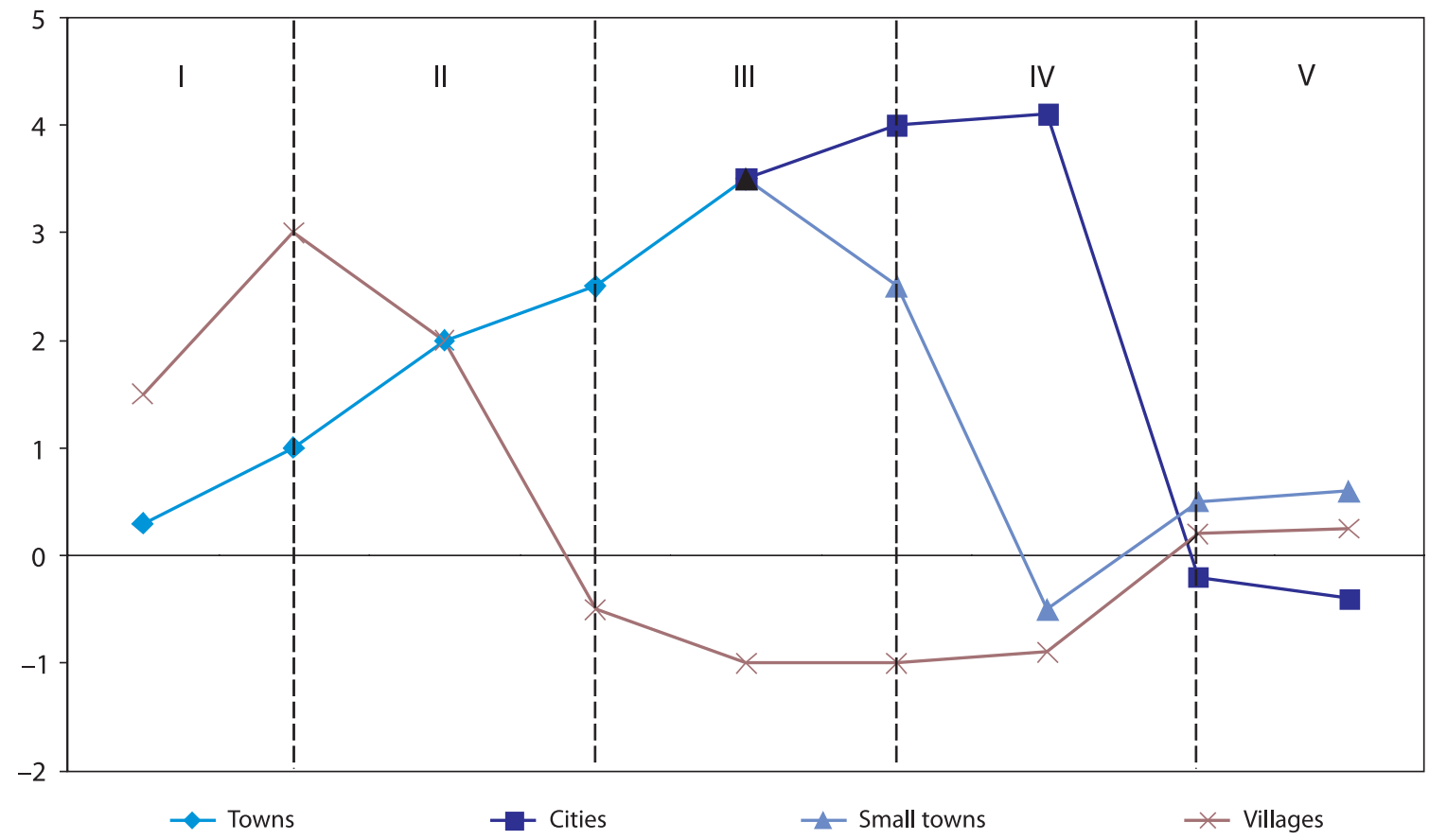

Fig. 1. Growth rates of various settlements (average annual values in arbitrary \%) and five stages of urbanization according to J. Gibbs (1963)

Source: J. Gibbs, 1963.

Transition of a number of highly urbanized regions of the world to the fifth stage of Gibbs' model in the early seventies promoted development of a universal concept of differential urbanization of H.S. Geyer and T.A. Kontuly (1993). This concept considers an urbanization process as the transition from a monocentric settlement system with large city domination to the polycentric settlement system with migration of population between cities of various ranks. This transformation is performed in three main stages, namely urbanization, polarization reversal and counterurbanization (fig. 2). At the first stage, large cities grow faster than the others thus forming monocentric settlement systems. The second stage is characterized by faster growth of medium-sized cities which form polycentric settlement systems, and the third stage shows faster growth of small cities. The third stage termination completes the first cycle of agglomerative processes and starts a new urbanization cycle, i.e. the transition to the first stage.

Russian researchers T.G. Nefedova and A.I. Treivish (Нефёдова, Трейвиш, 2005) tried to verify the differential urbanization scheme by Russian population dynamics, but could not confirm full compliance of theoretical ideas of authors of this concept with realities of Russia. However, that was to be expected because various regions of that vast country were at different urbanization stages and not all of them were involved in agglomerative processes.
Unfortunately, J. Gibbs (1963), H.S. Geyer and T.A. Kontuly (1993) provided no accurate criteria for classification of cities by population. H.S. Geyer and T.A. Kontuly (1993) have directly specified in their paper that uniform criteria for division of cities into large, medium-sized and small ones are absent at different stages of urban development since sizes of cities depend on world population, levels of transport and technology development and other factors.

According to E.A. Kolbina, S.N. Nayden (Колбина, Найден, 2013), a main defect of stadial and differential urbanization concepts is their abstract nature. They consider urbanization in ideal and homogeneous space, i.e. ignore peculiarities of spatial settlement structures of specific countries and regions.

It should be noted that the fifth urbanization stage of J. Gibbs (1963) and stages of the differential urbanization of H.S. Geyer and T.A. Kontuly (1993) characterize formation of urban agglomerations and the transition to formation of urbanized areas such as megapolises and conurbations. However, not all urban settlements are involved in these processes, i.e. this urbanization stage is not universal. In addition, small and medium-sized cities of urban agglomerations actually lose their independence and become satellites of urban agglomeration centers. Therefore, it is not quite legitimate to rank them as small and medium-sized cities. Population sizes of these cities have been eroded by agglomerative processes and turn into conventional indices, which do not make it possible to estimate adequately their 


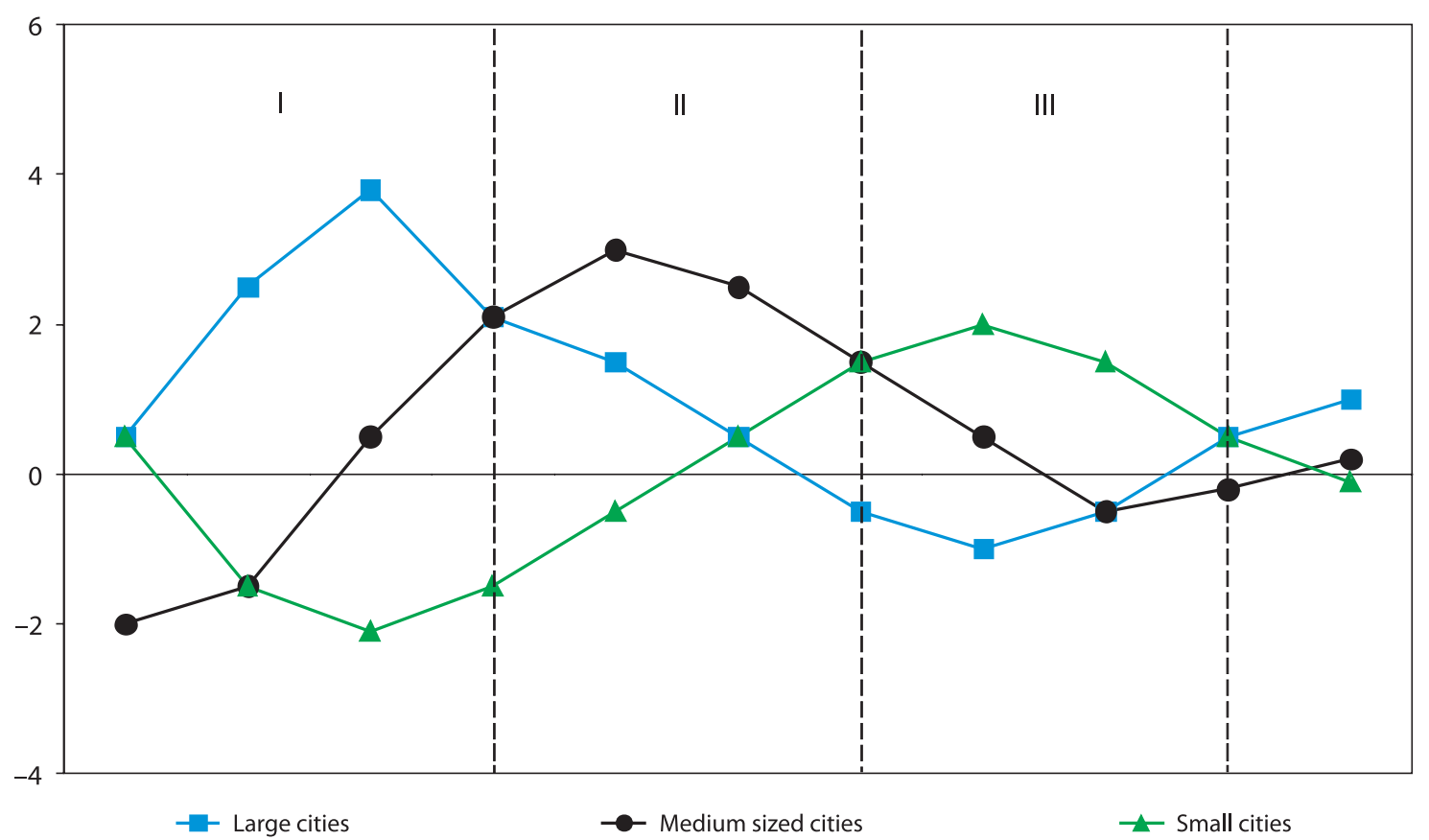

Fig. 2. Growth rates of various urban settlements (average annual values in arbitrary \%) and three stages of urbanization according to H.S. Geyer and T.A. Kontuly (1993)

Source: H.S. Geyer, T.A. Kontuly, 1993.

true role in any settlement system. That is why the place and role of a city in the settlement system, i.e. its functional typology is important now for analyzing the urbanization stadiality.

It seems that research of urbanization stadiality is to be considered from empirical points and based on analysis of development of specific settlement systems which have been formed historically and are integral rural-urban continuums, i.e. town areas according to V.O. Klyuchevsky (Ключевский / no data/). Their development is greatly affected by center-periphery processes (CPPs) occurring at various hierarchical levels. It also appears that combination of theoretical ideas about CPP with modern concepts of evolution of urban settlements can be a basis for construction of more specific and practice-oriented concepts of urbanization and regional development.

The Republic of Belarus may become a beneficial ground for researches of urbanization stadiality because of active CPPs of different hierarchical levels within its borders, the achieved high level of urbanization, and the presence of reliable statistics reflecting development of urban settlements for a number of last decades (1959-2017). In addition, a country scale makes it possible to consider development of all urban settlements of Belarus and not just of the most significant ones.

\section{Center-periphery processes and their role in regional and urban development}

A study of CPPs that are processes of polarization of geographical space resulting in differentiation of spatial structures with formation of centers and surrounding peripheral territories has long traditions in social and economic geography. A model of J.H. Thünen (Тюнен, 1926) that has made it possible to reveal the phenomenon of socio-geographical or nodal zonality in the case of an «lsolated State» can be considered to be one of the first attempts of such studies. Through researches of I. M. Wallerstein (Валлерстайн, 2001), J. Friedmann (1966) and their numerous followers, a center-periphery approach has been firmly established in science as a new universal scientific research method since the 1960s and 1970s.

The center-periphery approach involves division of an object of study into two (center and periphery) or three (center, semi-periphery and periphery) parts and research of their interrelations in the form of CPPs. These processes have a hierarchical nature and manifest themselves at global, national, regional and local levels (Ридевский, 2013). From the point of view of distribution of productive forces, that results in growth of urban centers and transformation of their systems of settlement, economic and environmental management (tab. 1).

Depending on the hierarchical level, one can mark out three main CPPs, namely metropolization, 
Tab. 1. Center-periphery processes and results of their manifestation

\begin{tabular}{|l|c|c|}
\hline Hierarchical levels of CPP manifestation & CPP & Results of CPP manifestation \\
\hline Global level & oligopolization & oligopolises, world cities \\
\hline National level & metropolization & metropolises \\
\hline Regional level & regionopolization & regionopolises (regiopolises) \\
\hline Local level & locopolization & locopolises \\
\hline
\end{tabular}

Source: Ридевский, 2013.

regionopolization and locopolization in the Republic of Belarus. Deconcentration processes are antipodes of the above ones and occur at national, regional, and local levels, too.

Metropolization is to be understood as the process of growth of the country's main urban center, usually the capital, in the course of its socio-economic, demographic, ecological and sociocultural development (Алаев, 2003). The metropolization process is particularly evident in concentration of population in a metropolis and its urban agglomeration.

The only metropolis of Belarus is its capital. From 1959 to the beginning of 2017 the population of Minsk has increased from 516 to 1974.8 thousand persons. Today, $20.8 \%$ of the country's population is concentrated in Minsk (fig. 3). In addition, the Minsk urban agglomeration is actively developed around the city. Except for Minsk, this agglomeration includes ten more urban settlements with the population exceeding 114.5 thousand persons in early 2017. Some satellites of Minsk are periodically included in its structure, for example, urban settlements of Socol, Vostochny, and Sosny were included in the structure of Minsk in the 1990s.

Regionopolization (regiopolization or regional metropolization according to E.B. Alayev (Алаев, 1983)) is a process similar to metropolization. In Belarus, it manifests itself within boundaries of intraregional areas, which are to be considered as integral systems of settlement, economic and environmental management or as social, ecological and economic regions (SEERs). These regions are historical town areas, some of them can be traced over centuries (Ридевский, 2003). A system of 15 SEER has formed in Belarus since the early 1970s (fig. 4). These regions in Belarus are spatial analogs of NUTS-2 regions, which are considered as the main objects of regional policy in the states of the European Union.

Thirteen SEERs of Belarus have a monocentric nature, i.e. each has a single clearly marked urban center called a regionopolis (regiopolis). Two SEERs have a polycentric nature, their centers consist of 2-3 regionopolises, for example, Soligorsk and Slutsk in the Soligorsk SEER and Krichev, Klimovichi and Kostyukovichi in the Krichev SEER.

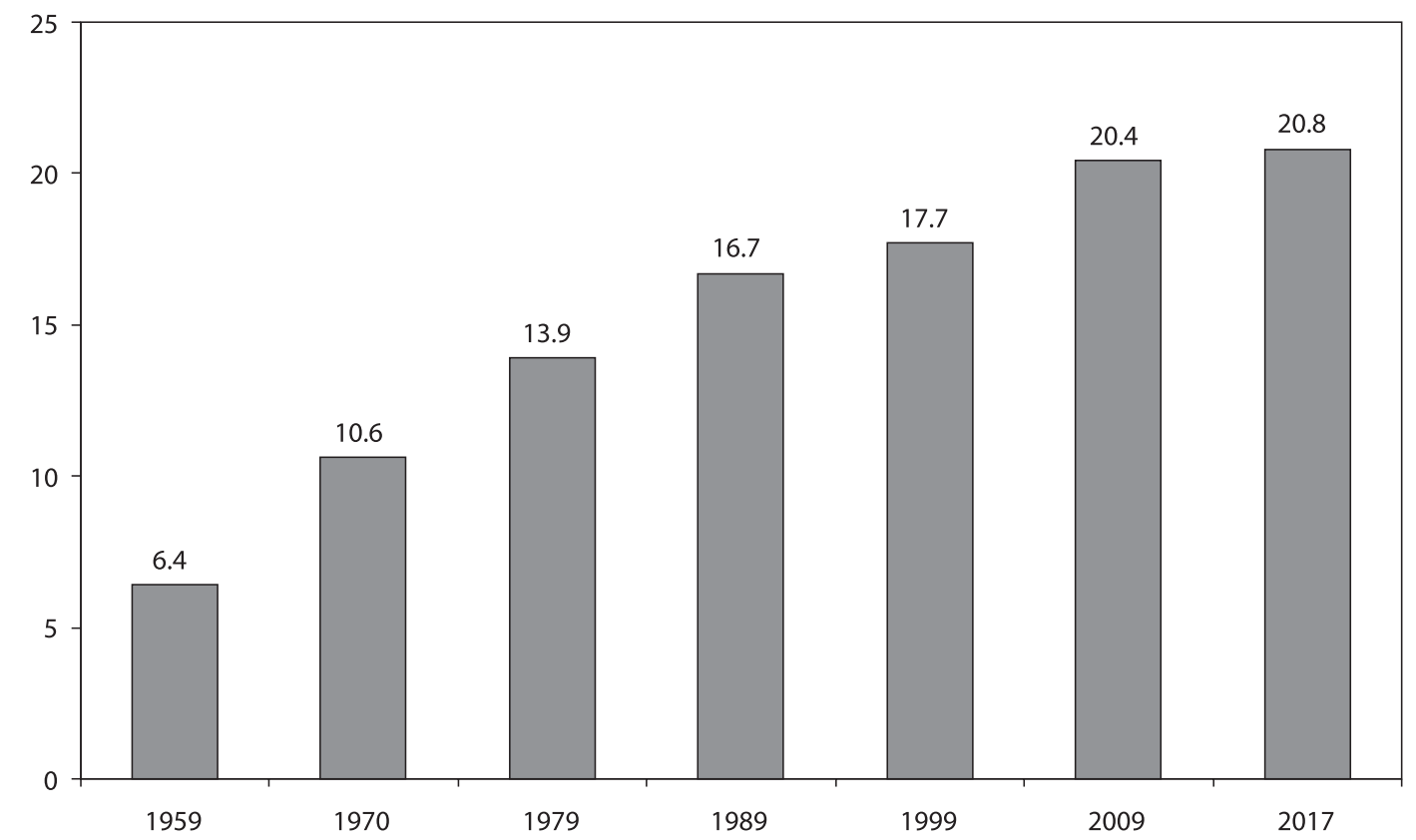

Fig. 3. Share of Minsk in the population of Belarus in 1959-2017, \%

Source: calculated on the base of data from (Перепись населения 2009..., 2010; Численность населения на 1 января 2017 ..., 2017). 


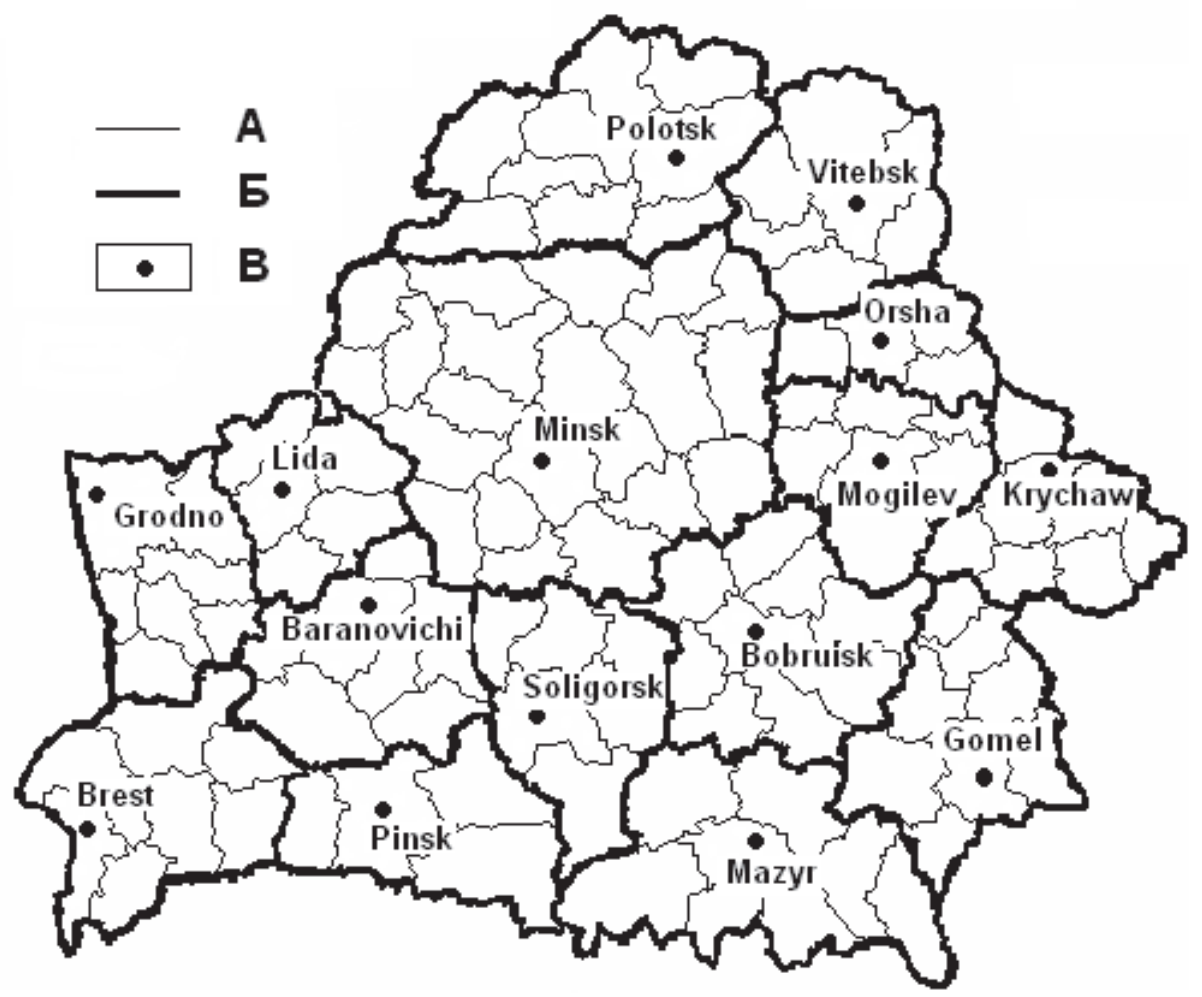

A - boundaries of administrative districts; $\overline{-}$ - boundaries of SEERs; B - centers of SEERs.

Fig. 4. Social, ecological and economic regions of Belarus since the early 1970s.

Source: Ридевский, 2003.

Two monocentric SEERs of Belarus are led by pair centers formed by almost united cities. These are Polotsk and Nopovopolotsk and Mozyr and Kalinkovichi, which are pair centers of the Polotsk and Mozyr SEERs, respectively.

In the Minsk SEER, one can mark out ex-regionopolises of Molodechno and Borisov, which led independent SEERs until the early 1970s and then became parts of the Minsk SEER as a result of essential expansion of a zone of direct influence of Minsk in the course of fast growth of its population and electrification of railway transport in surrounding areas. This is a classical example of the explosion or space compression due to development of transport infrastructure around a large urban center.

In the Bobruisk SEER, in addition to Bobruisk, one can mark out Zhodino, which is a quasi-regionopolis. Its population is significantly less than that in Bobruisk but its economic potential is considerably greater.

Data presented in table 2 show that regionopolization is general and natural in Belarus. In early 2017, $58.4 \%$ of the country's population lived in regionopolises including ex-regionopolises of Molodechno and Borisov and the quasi-regionopolis of Zhlobin. Allowing for interconnection of the population settlement with the economy distribution pattern and territorial arrangement of environmental management processes, one can say that regionopolization is a leading process in transformation of territorial systems of settlement, economy and environmental management.

Regressive regionopolization characterized by an increase in the regionopolis share in the SEER population and a decrease in the regionopolis population itself takes place in a number of SEERs of modern Belarus. In recent years, the regressive regionopolization has been observed in Bobruisk, Polotsk, Pinsk, Orsha and Krichev SEERs, i.e. in most of regionopolises of Belarus without the regional center status. This regionopolization is due to much slower reduction of the population of the regionopolis in comparison with that of its peripheral territories. In other SEERs, one can observe the progressive regionopolization accompanied with growth of both the regionopolis population and its share in the region population. Especially high rates of the regionopolization are in the Grodno, Brest and Minsk SEERs.

The role of locopolises in development of local settlement systems increases in the course of locopolization. Both small towns and large rural settlements can act as locopolises. Urban settlements being the centers of all administrative districts are considered as locopolises in table 3. Some of them 
Tab. 2. Regionopolization in SEERs of Belarus in 1970-2017 in terms of population concentration in regionopolises

\begin{tabular}{|l|l|l|l|l|l|l|}
\hline \multirow{2}{*}{$\begin{array}{c}\text { Social, ecological and economic } \\
\text { regions (SEERs) }\end{array}$} & \multicolumn{6}{|c|}{ Percentage of regional centers in the population size, \% } \\
\cline { 2 - 7 } & 1970 & 1979 & 1989 & 1999 & 2009 & 2017 \\
\hline Brest SEER & 21.6 & 29.3 & 37.9 & 40.2 & 44.9 & 48.5 \\
\hline Baranovichi SEER & 18.4 & 23.6 & 28.6 & 30.2 & 33.8 & 37.9 \\
\hline Pinsk SEER & 15.5 & 21.8 & 28.3 & 31.5 & 34.3 & 37.8 \\
\hline Vitebsk SEER & 48.1 & 56.7 & 62.0 & 63.6 & 70.2 & 73.9 \\
\hline Orsha SEER & 32.4 & 37.4 & 40.7 & 42.0 & 51.6 & 53.7 \\
\hline Polotsk SEER & 21.2 & 28.5 & 29.1 & 35.2 & 44.6 & 48.4 \\
\hline Gomel SEER & 35.4 & 45.4 & 53.9 & 56.5 & 61.1 & 64.5 \\
\hline Mozyr SEER & 16.5 & 24.7 & 34.4 & 41.4 & 45.9 & 50.0 \\
\hline Grodno SEER & 25.2 & 34.8 & 44.4 & 47.8 & 55.0 & 60.6 \\
\hline Lida SEER & 13.8 & 19.7 & 27.8 & 31.5 & 35.7 & 39.5 \\
\hline Minsk SEER & 38.8 & 47.0 & 52.3 & 54.5 & 59.1 & 61.3 \\
\hline Soligorsk SEER & 22.9 & 26.4 & 35.9 & 40.0 & 45.2 & 49.1 \\
\hline Mogilev SEER & 38.8 & 51.8 & 59.5 & 61.8 & 66.5 & 70.2 \\
\hline Bobruisk SEER & 22.3 & 29.8 & 32.2 & 32.7 & 34.9 & 36.8 \\
\hline Krichev SEER & 15.4 & 21.2 & 26.8 & 31.2 & 35.7 & 39.0 \\
\hline The Republic of Belarus & 29.0 & 37.7 & 44.8 & 47.3 & 52.4 & 55.0 \\
\hline
\end{tabular}

Notes: 1. Data for 1970-2009 are presented at the beginning of the corresponding population census, data for 2017 are presented at the beginning of the year. 2. Satellite towns are not included in regionopolises forming urban agglomerations. Settlements subordinated to Executive Committees of Novopolotsk, Vitebsk, and Gomel are included in Novopolotsk, Vitebsk, and Gomel, respectively. 3. The pair cities of Polotsk-Novopolotsk and Mozyr-Kalinkovichi are considered as regional centers of the Polotsk and Mozyr SEERs, respectively. 4. Regionopolises of Soligorsk and Slutsk and those of Krichev, Klimovichi and Kostyukovichi are considered as regional centers of the polycentric Soligorsk and Krichev SEERs, respectively. 5. Ex-regionopolises of Molodechno and Borisov and quasi-regionopolis of Zhlobin are not considered as regional centers of the Minsk and Bobruisk SEERs, respectively. 6 . Regional centers of all SEERs are considered as regional centers of the Republic of Belarus.

Source: calculated on the base of data from (Перепись населения 2009..., 2010; Численность населения на 1 января 2017, ..., 2017).

Tab. 3. Locopolization in administrative districts of Belarus in 1970-2016 in terms of population concentration in district centers

\begin{tabular}{|l|c|c|c|c|c|c|}
\hline & 1970 & 1979 & 1989 & 1999 & 2009 & 2016 \\
\hline Share of district centers in population of Belarus, \% & 40.6 & 52.2 & 62.5 & 66.1 & 71.3 & 74.6 \\
\hline $\begin{array}{l}\text { Share of district centers in urban population of } \\
\text { Belarus, \% }\end{array}$ & 93.4 & 95.0 & 95.5 & 95.3 & 95.9 & 96.2 \\
\hline $\begin{array}{l}\text { Number of districts with the administrative center } \\
\text { population share exceeding 80.0\% }\end{array}$ & 1 & 6 & 7 & 9 & 11 & 13 \\
\hline $\begin{array}{l}\text { Number of districts with the administrative center } \\
\text { population share in the range of 50.1 - 80.0\% }\end{array}$ & 13 & 14 & 23 & 26 & 36 & 47 \\
\hline $\begin{array}{l}\text { Number of districts with the administrative center } \\
\text { population share in the range of 30.1 - 50.0\% }\end{array}$ & 13 & 19 & 43 & 51 & 56 & 50 \\
\hline $\begin{array}{l}\text { Number of districts with the administrative center } \\
\text { population share not exceeding 30.0\% }\end{array}$ & 90 & 78 & 44 & 32 & 15 & 8 \\
\hline Total number of districts in the Republic of Belarus & 117 & 117 & 117 & 118 & 118 & 118 \\
\hline
\end{tabular}

Notes: 1. Centers of regions and Minsk were included in relevant districts; Novopolotsk and Zhodino were included in the Polotsk and Smolevichi districts, respectively. 2. Zhodino and Smolevichi were conditionally considered as the center of the Smolevichi district. The pair city of Polotsk-Novopolotsk was considered as the center of the Polotsk district. 3. Data of population censuses of 1970, 1979, 1989, 1999, and 2009 as well as current records of 2016 were used.

Source: calculated on the base of data from (Перепись населения 2009..., 2010; Численность населения на 1 января 2017, ..., 2017). 
are both the regionopolises and the regional centers. It is quite lawful because locopolization, regionopolization and metropolization processes intersect and overlap. The metropolis acts as the regionopolis and the locopolis with respect to the intraregional settlement system and the local one, respectively. Similarly, regionopolises also act as centers of local settlement systems.

Locopolization has a regressive nature in most of administrative districts. The progressive locopolization is typical only for a limited number of districts whose centers are regionopolises in general.

Formation of urban agglomerations or an agglomeration process can also be considered as CPP. According to E.B. Alayev (Алаев, 1983), the agglomeration process is concentration followed by territorial extension of a concentration core, resulting in the emergence of the agglomeration. In other words, it is a special CPP exhibiting itself in combination with oligopolization, metropolization, regionopolization and locopolization processes at global, country, regional and local levels.

Considering agglomeration processes as CPPs of a special type, all CPPs can be divided into two groups: geographically structured CPPs exhibiting themselves in the territory of a certain hierarchical level (oligopolization, metropolization, regionopolization, locopolization) and geographically indifferent CPPs (end-to-end or elastic) exhibiting themselves at global, country, regional and local levels (agglomeration processes).

At the beginning of 2017, 18 urban agglomerations uniting 55 urban settlements can be marked out in Belarus. Formation of urban agglomerations of Belarus is more evident in combination with processes of metropolization (the Minsk urban agglomeration), regionopolization (agglomerations of regional centers and most of the main regionopolises which are SEER centers), and locopolization (agglomeration of small towns).

\section{Functional typology of urban settlements of Belarus}

Allowing for metropolization, regionopolization and locopolization processes, one can propose the typology of urban settlements of Belarus in accordance with their places in the territorial structure of settlement, economy, and environmental management. This typology can be called the functional one because it reflects functions that are executed by an urban center for associated territories.
All urban settlements of the country can be categorized into six main types (orders) (Ридевский, 2016):

1. Metropolis (Minsk) and urban settlements of a metropolitan area (Minsk urban agglomeration). The metropolis and urban settlements of the metropolitan area are developed under the influence of the metropolization process.

2. Regionopolises of the first order include most significant cities with the status of centers of regions, which are administrative and territorial units of Belarus of a subnational level. Regional capitals are centers of SEERs and differ significantly from other regionopolis of Belarus for most parameters. All regional centers lead corresponding urban agglomerations.

3. Regionopolises of the second order include main centers of other SEERs, namely Mozyr, Bobruisk, Krichev, Orsha, Polotsk, Soligorsk, Pinsk, Baranovichi, and Lida SEERs. Ex-regionopolises of Molodechno and Borisov as well as the quasi-regionopolis of Zhlobin, which is actively claiming to be the regionopolis in the Bobruisk SEER, should also be included in this group of cities. Most of the second-order regionopolises also lead urban agglomerations.

4. Regionopolises of the third order and subregional centers. Third-order regionopolises are non-principal urban centers of polycentric Soligorsk and Krichev SEERs (Slutsk, Klimovichi, and Kostyukovichi). Subregional centers are centers of settlement and social services for two or three nearest administrative districts. Subregional centers of Svetlogorsk and Volkovysk became centers of urban agglomerations.

5. Locopolises of the first order are towns and urban villages and involve administrative district centers not included in the groups mentioned above. Locopolises of Nesvizh, Stolin, and Ivatsevichi became centers of urban agglomerations.

6. Other urban settlements (locopolises of the second order). This group includes small urban settlements without the status of administrative district centers but many of them performed administrative functions in the past. Most of the settlements of this group are actual locopolises for territorial settlement systems of a district level and today some urban settlements are almost identical to the rural ones.

Basing on the typology proposed above, all types of urban settlements of Belarus for early 2017 are shown in table 4.

Six types of urban settlements of Belarus can be divided into three groups, namely cities of national significance (metropolis and all first and second 
Tab. 4. Typology of urban settlements of Belarus, 2017

\begin{tabular}{|c|c|}
\hline $\begin{array}{l}\text { Types of urban } \\
\text { settlements }\end{array}$ & Urban settlements \\
\hline $\begin{array}{l}\text { Metropolis and } \\
\text { urban settlements } \\
\text { of the metropolitan } \\
\text { area }\end{array}$ & $\begin{array}{l}\text { Minsk (with Zaslavl, Fanipol, Dzerzhinsk, Smolevichi, Logoysk, Rudensk, Smilovichi, Radoshkovichi, } \\
\text { Machulishchi, Svisloch) }\end{array}$ \\
\hline $\begin{array}{l}\text { Regionopolises of } \\
\text { the first order }\end{array}$ & $\begin{array}{l}\text { Vitebsk (with Ruba), Mogilev (with Shklov), Gomel (with Bolshevik, Dobrush, Vetka), } \\
\text { Grodno (with Skidel, gp Sopotskin), Brest (with Zhabinka) }\end{array}$ \\
\hline $\begin{array}{l}\text { Regionopolises of } \\
\text { the second order }\end{array}$ & $\begin{array}{l}\text { Bobruisk (with Kirovsk), Polotsk-Novopolotsk (with Borovukha, Vetrino), Baranovichi (with Lyakhov- } \\
\text { ichi), Pinsk, Orsha (with Baran, Bolbasovo, Kopys, Orekhovsk), Mozyr-Kalinkovichi, Lida, Soligorsk } \\
\text { (with Starobin), Krichev, Borisov (with Zhodino, Zelenyi Bor), Molodechno, Zhlobin }\end{array}$ \\
\hline $\begin{array}{l}\text { Regionopolises of } \\
\text { the third order and } \\
\text { subregional centers }\end{array}$ & $\begin{array}{l}\text { Slutsk, Klimovichi, Kostyukovichi, Postavy, Glubokoe, Lepel, Gorki, Osipovichi, Rogachev, Svetlogorsk } \\
\text { (with Sosnovyi Bor), Rechitsa, Luninets, Kobrin, Bereza, Slonim, Novogrudok, Volkovysk (with Ross } \\
\text { and Krasnoselsky), Vileyka, Smorgon }\end{array}$ \\
\hline $\begin{array}{l}\text { Locopolises of the } \\
\text { first order }\end{array}$ & $\begin{array}{l}\text { Bykhov, Klichev, Mstislavl, Slavgorod, Chausy, Cherikov, Berezino, Volozhin, Kletsk, Kopyl, Krupki, } \\
\text { Lyuban, Myadel, Nesvizh (with Gorodeya), Mar'ina Gorka, Starye Dorogi, Stolbtsy, Uzda, Cherven, } \\
\text { Gantsevichi, Drogichin, Ivanovo, Ivatsevichi (with Kosovo), Kamenets, Malorita, Pruzhany, Sto- } \\
\text { lin (with Rechitsa), Dyatlovo, Iv'e, Mosty, Oshmyany, Svisloch, Shchuchin, Buda-Koshelevo, Elsk, } \\
\text { Zhitkovichi, Narovlya, Petrikov, Hoyniki, Chechersk, Braslav, Verkhnedvinsk, Gorodok, Dokshitsy, Du- } \\
\text { brovno, Miora, Senno, Tolochin, Chashniki, Belynichi, Glusk, Dribin, Krasnopol'e, Krugloe, Khotimsk, } \\
\text { Bol'shaya Berestovitsa, Voronovo, Zel'va, Korelichi, Ostrovets, Bragin, Korma, Lel'chitsy, Loev, } \\
\text { Octyabr'sky, Beshenkovichi, Liozno, Rossony, Ushachi, Sharkovshchina, Shumilino }\end{array}$ \\
\hline $\begin{array}{l}\text { Other urban settle- } \\
\text { ments (locopolises } \\
\text { of the second order) }\end{array}$ & $\begin{array}{l}\text { Beryozovka, Beloozersk, Vysokoe, Mikashevichi, David-Gorodok, Turov, Vasilevichi, Novolukoml, Dis- } \\
\text { na, Bobr, Ivenets, Kholopenichi, Pleshchinitsy, Urech'e, Krivichi, Svir, Krasnaya Sloboda, Gorodishche, } \\
\text { Domachevo, Antopol, Telekhany, Logishin, Shereshovo, Ruzhany, Radun, Novoelnya, Kozlovshchina, } \\
\text { Yuratishki, Mir, Lyubcha, Porozovo, Zheludok, Ostrino, Komarin, Uvarovichi, Streshin, Zarech'e, Terek- } \\
\text { hovka, Ozarichi, Kopatkevichi, Parichi, Vidzy, Osvea, Surazh, Podsvil'e, Yanovichi,Ezerishche, Begoml, } \\
\text { Voropaevo, Lyntupy, Bogushevsk, Kokhanovo, Obol, Naroch, Elizovo, Tatarka, Pravdinsky. }\end{array}$ \\
\hline
\end{tabular}

Note: Urban settlements in parentheses are satellite towns included in relevant urban agglomerations.

Source: urban settlements are presented as at 1 January 2017 in accordance with (Численность населения на 1 января 2017, ..., 2017).

Tab. 5. Number, population and share of main types of urban settlements in total and urban population of Belarus at early 2017

\begin{tabular}{|l|c|c|c|c|}
\hline \multicolumn{1}{|c|}{ Type of urban settlements } & $\begin{array}{c}\text { Number of urban } \\
\text { settlements }\end{array}$ & $\begin{array}{c}\text { Average population } \\
\text { of an urban settle- } \\
\text { ment (thousands) }\end{array}$ & $\begin{array}{c}\text { Share in urban } \\
\text { population } \\
\text { of the country (\%) }\end{array}$ & $\begin{array}{c}\text { Share in total } \\
\text { population } \\
\text { of the country (\%) }\end{array}$ \\
\hline Cities of national significance & $18(49)$ & 323.5 & 78.7 & 61.3 \\
\hline Metropolis & $1(11)$ & 2089.3 & 28.2 & 22.0 \\
\hline First order regionopolises & $5(13)$ & 415.4 & 28.1 & 21.9 \\
\hline Second order regionopolises & $12(25)$ & 138.0 & 19.1 & 17.4 \\
\hline $\begin{array}{l}\text { Urban settlements of regional } \\
\text { significance }\end{array}$ & $90(96)$ & 15.7 & 9.4 & 7.3 \\
\hline $\begin{array}{l}\text { Third order regionopolises and } \\
\text { subregional centers }\end{array}$ & $19(22)$ & 36.5 & 9.7 & 7.5 \\
\hline First order locopolises & $71(74)$ & 10.1 & 2.2 & 1.8 \\
\hline $\begin{array}{l}\text { Urban settlements of local } \\
\text { significance }\end{array}$ & 57 & 2.9 & 2.2 & 1.8 \\
\hline Other urban settlements & 57 & 2.9 & 100.0 & 77.9 \\
\hline In total & $165(202)$ & 44.9 & & 7.3 \\
\hline
\end{tabular}

Notes: 1. The number of urban settlements is specified without satellite towns, i.e. urban settlements entering urban agglomerations of Belarus. The number of all urban settlements of a group including satellite towns is specified in parentheses. 2 . The average population of urban settlements is calculated without satellite towns. 3 . Shares of various groups of urban settlements in urban and total population of the country are calculated allowing for satellite towns.

Source: calculated on the base of data from (Численность населения на 1 января 2017 ..., 2017). 
order regionopolises), urban settlements of regional significance (third order regionopolises, subregional centers and first order locopolises) and urban settlements of local significance (second order locopolises).

Cities of national significance are a basis of the structure of settlement of total and urban population of the country (tab. 5).

\section{Urbanization stadiality in Belarus}

Using a population growth rate for different types of urban settlements of Belarus as an indicator, three main stages of urbanization can be marked out in Belarus between 1959 and 2015. (tab. 6; fig. 5).

First stage. The stage of general urbanization (1959-1989). Population grew in all types of urban settlements of the country. The highest population growth rates were observed in cities of national significance, and especially in Minsk and its metropolitan area. The share of citizens in the country's population increased from 31.1 to $68.6 \%$. Cities of national significance concentrated $69.1 \%$ of the urban population by the end of the period under consideration.

Tab. 6. Dynamics of population for various types of urban settlements and stages of urbanization in Belarus between 1959 and 2015 in percents as compared to the corresponding census year

\begin{tabular}{|c|c|c|c|c|}
\hline \multirow{3}{*}{ Types of settlements } & \multicolumn{3}{|c|}{ Stages of development of urbanization } & \multirow{3}{*}{$2017 / 195$} \\
\hline & I & II & III & \\
\hline & $1989 / 1959$ & $1999 / 1989$ & $2017 / 1999$ & \\
\hline Metropolis and settlements of the metropolitan area & 306.8 & 104.9 & 117.6 & 378.4 \\
\hline First order regionopolises & 287.8 & 101.2 & 112.2 & 326.9 \\
\hline Second order regionopolises & 284.0 & 105.9 & 102.2 & 304.0 \\
\hline Urban settlements of regional significance & 236.3 & 106.3 & 95.1 & 238.7 \\
\hline Third order regionopolises and subregional centers & 261.0 & 108.7 & 96.8 & 274.4 \\
\hline First order locopolises & 217.7 & 104.1 & 93.5 & 212.0 \\
\hline Urban settlements of local significance & 116.7 & 99.2 & 79.5 & 92.0 \\
\hline Other settlements & 116.7 & 99.2 & 79.5 & 92.0 \\
\hline All urban settlements & 266.6 & 104.2 & 106.3 & 295.4 \\
\hline Rural settlements & 63.0 & 87.9 & 68.2 & 37.7 \\
\hline All settlements of the country & 126.0 & 99.0 & 94.6 & 118.0 \\
\hline
\end{tabular}

Source: calculated on the base of data from (Перепись населения 2009..., 2010; Численность населения на 1 января 2017..., 2017).

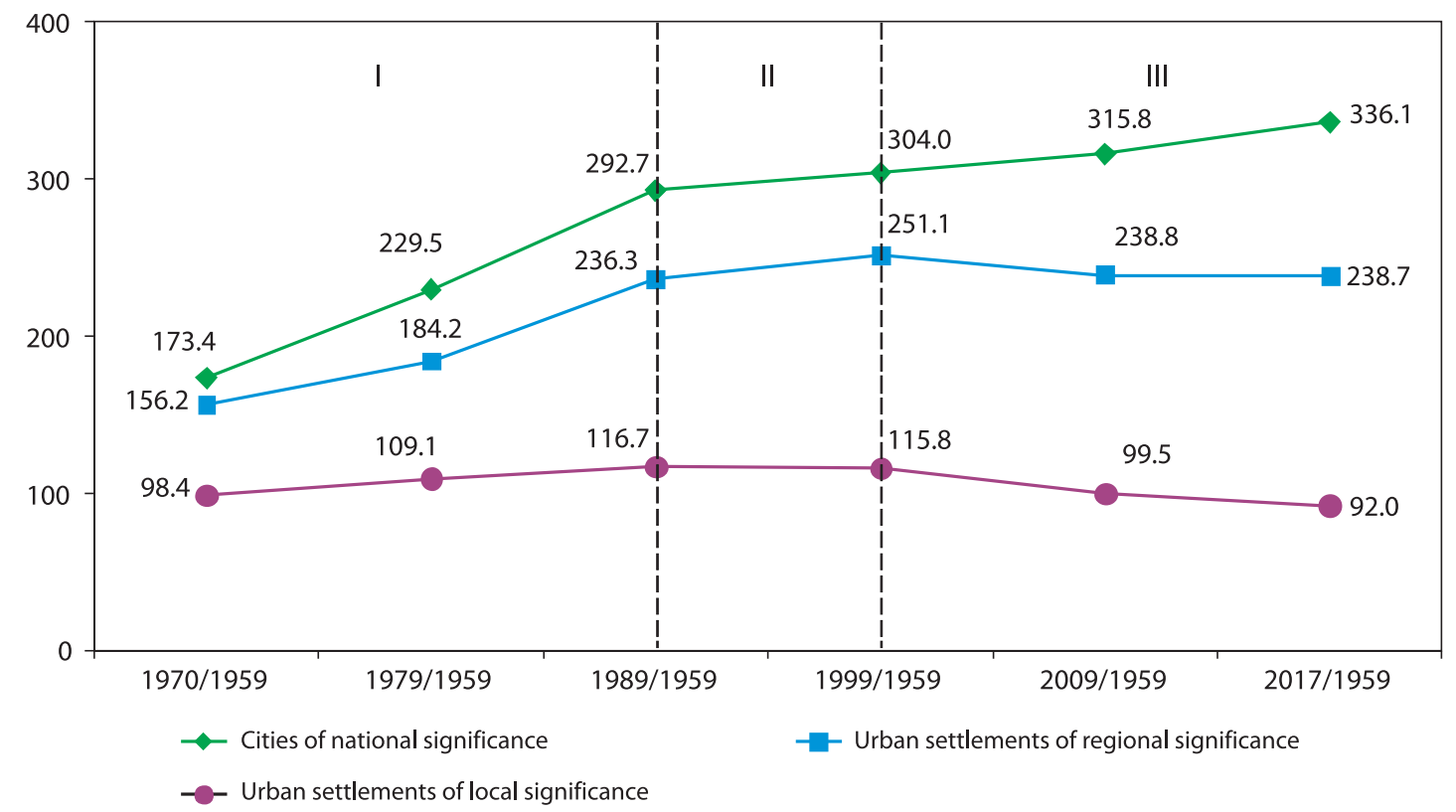

Fig. 5. Growth rates of main functional types of urban settlements and three stages of urbanization in Belarus between 1959 and 2017, in \% as compared to 1959.

Source: calculated on the base of data from (Перепись населения 2009.., 2010; Численность населения на 1 января 2017..., 2017). 
Second stage. The stage of polycentric two-level urbanization (1989-1999). Cities of national and regional significance continued their growth, population of other urban settlements or second order locopolises began to go down. Highest population growth rates were observed in cities of regional significance and especially in third order regionopolises and subregional centers. The share of citizens increased from 68.6 to $69.3 \%$. By the end of the period, population of cities of national significance reached $75.7 \%$ of the urban population and exceeded half $(52.4 \%)$ the total population of the country for the first time.

Third stage. The stage of polycentric one-level urbanization (1999-2017). Population increases only in cities of national significance. Cities of regional significance began to depopulate thus joining cities of local significance. Highest rates of urban population growth are observed in Minsk and its metropoli$\tan$ area. The share of citizens reached $77.9 \%$ of total population. In early 2017 , cities of national significance concentrated $78.7 \%$ and $61.3 \%$ of urban and total population, respectively.

\section{Main conclusions}

Application of the center-periphery approach is greatly significant for researches of urbanization processes because it gives fresh insights into typology of urban settlements and identification of main stages of their growth. It is important for further development of regional researches and optimization of regional policy. The presented researches make it possible to draw a number of methodological and practice-oriented conclusions based on materials of development of urban settlements of Belarus:

1. As intensive center-periphery processes take place in any country of the world, in order to reveal stages in urbanization development, urban growth rates based on formal criteria of population size are not as important as a place of cities in the relevant settlement system, i.e. their functional typology determined by nature and hierarchical levels of center-periphery processes they are involved in. The concept reflecting urbanization stadiality based on functional typology of urban settlements can be called the functional urbanization concept.

2. A proposed scheme of urbanization stadiality in Belarus in 1959-2017 is based on functional typology of urban settlements allowing for active agglomeration processes and makes it possible to predict the outlined transition to the next fourth stage of urbanization. Just like second and third stages, this stage will be focal and initiate depopulation of second order regionopolises, i.e. urban settlements leading large territorial systems of settlement, economic and environmental management or SEERs. This stage can be called the stage of oligocentric urbanization, i.e. urbanization of a few urban centers (from Greek oligos - few). Minsk and its actively developing urban agglomeration can further become the only center of demographic and economic growth in the country (the possible fifth stage of monocentric urbanization).

3. As all SEERs are nodal in nature, their leading regionopolises are the link between central and peripheral regions thus materializing the unity of the center and the periphery. Depopulation of these urban centers can have extremely negative effects on social and economic development of corresponding SEERs. At the same time, monocentric development of the country is an active threat to further development of the state as it generates overconcentration of the population, economy and environmental management processes and intensifies social, economic, and environmental problems.

4. Revealed and predicted stages of urbanization are indicative of competition of polycentric and monocentric models of the territorial structure of Belarus during the second half of the 20th century and the beginning of the 21st century. It is evident that the strategy of polycentric development that can be achieved through active regional policy aimed at the sustainable and inclusive development is to be the optimum one for territorial development of the country.

5. Special measures of regional and macroeconomic policy can preserve a polycentric model of further development of Belarus allowing for the polycentric nature of settlement, economic and environmental management and the hierarchy of center-periphery processes that constantly reproduce polycentrity of the territorial structure of the state. The most important measures are: strategic programming of social and economic development; territorially differentiated regional policy; state regulation of a remuneration system through convergence in the minimum and average wage levels; and other effective measures.

6. It is evident that territorial systems of settlement, economic and environmental management or SEERs in Belarus should be considered as main objects of regional policy aimed at sustainable and inclusive development. These SEERs can be regarded as analogs of NUTS-2 regions that 
which are main objects of regional policy in the European Union countries.

\section{References}

Friedmann J., 1966, Regional Development Policy: A Case Study of Venezuela, MIT Press, Cambridge.

Geyer H.S., Kontuly T.A., 1993, A Theoretical Foundation for the Concept of Differential Urbanization, International Regional Science Review, 5(2), 157-177.

Gibbs J., 1963, The Evolution of Population Concentration, Economic Geography, 2, 119-129.

Алаев Э.Б., 1983, Социально-экономическая география: Понятийно-терминологический словарь, Мысль, Москва.

Валлерстайн И.М., 2001, Анализ мировых систем и ситуация в современном мире, Университетская книга, Санкт-Петербург.

Ключевский В.О., /no data/, Курс русской истории. Лекция IX. http://www.kulichki.com/inkwell/text/special/history/ kluch/kluch09.htm [07.03.2017].

Колбина Е.О., Найден С.Н., 2013, Эволюция процессов урбанизации на Дальнем Востоке России, Пространственная экономика, 4, 44-69.

Нефёдова Т.Г., Трейвиш А.И., 2005, Теория «дифференииальной урбанизации» и иерархия городов в России на рубеже XXI века, Демоскоп Wekle, 217-218, http:// www.demoscope.ru/weekly/2005/0217/analit01.php [07.03.2017].

Перепись населения 2009. Население Республики Беларусь: его численность и состав, Т.2, 2010, Национальный статистический комитет Республики Беларусь, Минск.

Ридевский Г.В., 2003, Социально-эколого-экономическое районирование Республики Беларусь, [in:] Восточная Европа: вопросы исторической, общественной и политической географии. Сборник научных статей, Издательство ПГПИ, Псков, 87-96.

Ридевский Г.В., 2013, Центр-периферийные процессы В расселении населения современной Беларуси, Региональные исследования, 2, 94-99.

Ридевский Г.В., 2016, Типология городских поселений и стадиальность урбанизации в Беларуси, [in:] Проблемы и перспективы сочиально-экономической географии (к 100-летию со дня рождения И.И. Трухана): материалы межд. научно-практ. конф., 12-14 ноября 2015 г., БГУ, Минск, 178-181.

Тюнен И.Г., 1926, Изолированное государство, Экономическая жизнь, Москва.

Численность населения на 1 января 2017 г. и среднегодовая численность населения за 2016 год по Республике Беларусь в разрезе областей, районов, городов, поселков городского типа, 2017, Национальный статистический комитет Республики Беларусь, Минск. 